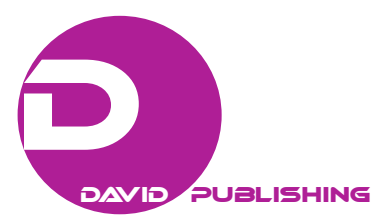

\title{
Open Innovation: A Systematic Literature Analysis
}

\author{
Beatrice Orlando \\ Sapienza University of Rome, Rome, Italy
}

\begin{abstract}
What is open innovation? There are different definitions of open innovation, depending, at least, on three parameters: source, ownership, or users of the knowledge linked to innovation. The aim of the paper is to make a systematic literature review, to map open innovation studies, and to re-conceptualize the openness according to two dimensions: degree of technology convergence and ontology of openness. In particular, we propose a classification of open innovation, based on the distinction between the originator/developer of the knowledge and the user. Users are a ubiquitous category, because they can be originators, as well as customers of the innovation itself. Therefore, we point out that there are three types of open innovation, whose degree of openness is defined according to an ontological dimension: at users' level, at an industry level, and among different fields or industries. Firm's structure affects the propensity to open innovation adoption; and the type of innovation itself. Finally, we identify another literature gap: the relationship between the open innovation model and grand challenge. Even if open innovation seems to be ideally connected to grand challenges and many industries actually adopt this model, there seems to emerge a gap in literature. Therefore, we propose a conceptual model for future researches.
\end{abstract}

Keywords: open innovation, systematic literature review, Grand Challenges

\section{Introduction}

Open innovation is gaining a great momentum. Despite the popularity of the topic both at an academic and at a practical level, it is still not clear what open innovation actually is. One central concern among scholars is the openness dimension (Dahlander \& Gann, 2010). Chesbrough (2003a; 2003b) anchors openness to permeability of firm's boundaries. West and Gallagher (2006) look at R\&D contributors. Huizingh (2011) studies open innovation according to three dimensions: context, content, and process. Mostly, open innovation is defined in contrast to closed innovation, and this approach generates overlapping between the two constructs, as well as the misleading idea that open innovation is “old wines in new bottles” (Trott \& Hartmann, 2009).

There's a lavish stream of literature on the topic, and likewise attempts to make recognition of antecedent literature. However, it seems to emerge a gap on the linkage between open innovation and technological convergence: as a matter of fact, open innovation is only possible when there's such convergence, despite the merely openness of firm boundaries or directions of the knowledge flow. The emblematic example is the worldwide web. Another gap regards the relationship between open innovation and grand challenges, although these two concepts are strictly related, at an ideal level. The aim of current paper is to review systematically the literature on open innovation, using several level of analysis. The review has different ends: identifying

Beatrice Orlando, Ph.D., adjunct professor of Strategies for Business Growth, Department of Management, Sapienza University of Rome, Rome, Italy.

Correspondence concerning this article should be addressed to Beatrice Orlando, Department of Management, Sapienza University of Rome, Rome Castro Laurenziano 9, 00161, Italy. 
recurrent or alternative definitions of open innovation; mapping main and critical gaps; understanding drivers of open innovation; ontology of openness and main proxy measures; depicting the level of analysis of previous studies.

Therefore, we re-conceptualize open innovation types in terms of technological convergence and ontology of openness. In fact, both two factors are poorly considered by antecedent contribution, in particular as coupled variables. Our main assumption is that convergence of technology_used in a broad sense-is the main driver of open innovation. It is defined at a structural level and it determines both firm's absorptive capacity, in case of external adoption, and possibilities of cross-organizational cooperation. On other terms, the permeability of firm borders depends on structural isomorphism, which is defined in terms of technology. The greater is isomorphism among cooperating partners, the more is openness as well.

An extremely complex type of innovation is one concerning grand challenges. Grand challenges require by definition an intense cooperation for the production of the target innovation. This is properly open innovation logic. Surprisingly, it is a neglected topic in previous studies on open innovation, even though is such an intense kind of technological innovation.

We identify three ontological dimensions of openness: at a user level, when the organization is open toward the final user, who is involved in the coproduction of innovation; at an industry level, when the firm is open toward partners operating in the same sector; at a cross-organizational level, when different actors coproduce a high complex innovation, even if they come from different fields. This last type requires the higher degree of openness, as in case of Grand Challenges.

The remainder of the paper is structured as follows: first, we systematically map antecedent literature, using multiple criteria of analysis; second, we propose a novel taxonomy for distinguishing open innovation type; finally, we underscore what are the managerial and practical implications, as well as critical future avenues.

\section{Clarifications on Methodology}

Current review is based on a systematic analysis. In addition, we have included at hand some other relevant contributions, to provide an up-to-date and extensive view on open innovation. Relevant contributions may include handbooks and other publications on different outlets.

First, we have analyzed most relevant antecedent studies, using over-time citations as main criterion for papers selection. This preliminary analysis is also helpful to identify main streams in literature and antecedent review results. Different key-words were used for searching on Google Scholar database, and, namely, they are: open innovation; open innovation and grand challenge; open innovation definition; open innovation literature review. Papers and other contributions were collected from the first 10 pages—since results were ordered for relevance. This collection phase was repeated in each search for the specific key word. Inclusion in our set was also based on the following factors: pdf availability; English language; relative consistency of citations' number; focus and coherence with open innovation topic. Since the criterion of citations' number can be poorly applied to recent contributions; they were weighed and selected for relevance and aim of the journal. In particular, the list of outlets includes only outstanding journals, in the field of business management and innovation. Several journal rankings are available online; hence, final journals' list was obtained from the comparison among different rankings. The rough initial selection and inclusion of contributions was hand refined in a later moment. Results were cleaned using a hierarchical ranking criterion (top cited antecedent papers and recent works, 
which relevance was based on Journal impact factor). Tables of analyzed papers are reported in appendix. Each paper was mapped using multiple criteria: paper references; field; key words; abstract; field; theory/topic; main definition of open innovation; ontology of openness; technological convergence; level of analysis (individual; structural; or organizational); proxy of open innovation; function of open innovation adoption (intrinsic value or bandwagon; and type of paper (conceptual; empirical; or both of them). Further specifications of mapping criteria are reported in the remainder of the paper. In total, we have analyzed and mapped 103 papers.

\section{Main Previous Literature Reviews and Gaps Tackled by the Paper}

In recent years, a real “epistemic community” (West, Salter, Vanhaverbeke, \& Chesbrough, 2014, p. 807) has been formed around the term open innovation. This "buzz word” (Giannopoulou, Yström, Ollila, Fredberg, \& Elmquist, 2010, p. 163) was used in many different contexts and review articles (Enkel, Gassmann, \& Chesbrough, 2009; Dahlander \& Gann, 2010; West \& Bogers, 2014).

Previous reviews (Elmquist, Fredberg, \& Ollila, 2009) identify seven streams of theoretical open innovation research: notion of open innovation; business models; organizational design and boundaries of the firm; leadership and culture; tools and technologies; intellectual property; industrial dynamics and manufacturing.

Using a structured content analysis, later works (Giannopoulou et al., 2010) extend the mentioned categorization as follows: (1) open innovation: the development of the concept; (2) organizational design and boundaries of the firm; (3) open strategy; (4) the human factor in open innovation, culture, and leadership; (5) communities for distributed co-creation with customers and other collaborating actors; (6) IP, patenting and appropriation; (7) innovation intermediaries: a new business model arising; (8) the triple helix: academia, industry, government policy.

Dahlander and Gann (2010) develop an analytical frame by structuring the analysis into two dimensions: inbound and outbound versus pecuniary and non-pecuniary.

Lichtenthaler (2011) identifies four streams of open innovation researches: technology transactions; user innovation; business models; and innovation markets.

Schroll and Mild (2012) review the state-of-the-art of empirical open innovation researches, focusing on large-scale and quantitative-oriented studies along four key dimensions: first, different methods of measuring open innovation adoption are compared; second, the level of open innovation adoption is analyzed on a general basis; third, the level of adoption is compared to open innovation mode (inbound and outbound); finally, they analyze drivers of open innovation adoption through different studies.

The review of West and Boger (2014) is mostly concerned with customer level and external open innovation adoption, and it frames the process into four major steps: obtaining innovations, which is the "inbound" step of inbound open innovation; integrating innovations; commercializing innovations; and interaction mechanisms.

Other scholars (B. R. Wikhamn \& W. Wikhamn, 2013), using a bibliometric method, analyze the emerging field of open innovation in terms of interrelated perspectives: the firm perspective and the ecosystem perspective. Finally, they introduce an integrated framework for open innovation and show how various concepts are related to each other under the umbrella of open innovation. Another stream of literature review explores the relationship between open innovation and performance (Greco, Grimaldi, \& Cricelli, 2015). Authors propose a novel taxonomy, consisting of four categories (inbound, outbound, coupled, and internal), 
six sub-classes (strategies, customers, suppliers, research institutions, competitors, foreign organizations), and two dimensions (depth and breadth).

The results and focus of main previous review works can be framed in the following concepts:

- identification of main research streams in open innovation;

- identification of open innovation types, proxy variables, and taxonomies of openness;

- mapping of the drivers of open innovation adoption.

Studies most employ bibliometrical and content analysis methods. Their results show that the most popular levels of analysis are the ecosystem and the firm ones. The relationship that attracted the most scholars' attention was the one with firm's performance.

In light of above considerations, current systematic analysis outlines at least three main gaps in previous works: ambiguity effect on open innovation adoption decision; structural constraints, such as technological convergence; grand challenge as an ecosystem of cooperators based on the open innovation model. Our attempt is to assess formerly listed gaps, proposing a fresh conceptual framework for open innovation.

\section{What Is Open Innovation?}

Current systematic literature review can be structured in three main parts: first, an early classification of studies, based on open innovation definition and conceptual framework; second, we group previous works proposing a novel taxonomy of open innovation. Specifically, we distinguish three main types of open innovation, according to two dimensions of analysis: technological convergence and ontology of openness; third, previous works are categorized for level of analysis: individual, organizational, structural, proxy variables, and function of adoption.

\section{Definition and Classification in Antecedent Literature}

Most studies frame open innovation in terms of organizational theory and organizational learning (Bianchi, Cavaliere, Chiaroni, Frattini, \& Chiesa, 2011; Lazzarotti \& Manzini, 2009; Sieg, Wallin, \& Von Krogh, 2010; Vanhaverbeke, Van de Vrande \& Chesbrough, 2008; Dahlander, Frederiksen, \& Rullani, 2008).

The term "open innovation” was introduced in Chesbrough's book in 2003, which outlined a new paradigm for innovation as antithesis of the traditional vertical integration model in which internal innovation activities lead to internally developed products and services that are then distributed by the firm (Chesbrough, 2012).

Since that time, the concept has been adopted by a wealth of academic articles.

Many authors take inspiration from the definition given by Chesbrough (2003a; 2003b; 2006, p. 1), according to which open innovation can be defined as "the use of purposive inflows and outflows of knowledge to accelerate internal innovation, and expand the markets for external use of innovation, respectively" (Vanhaverbeke, Van de Vrande, \& Chesbrough, 2008; Bogers, 2011). For Lichtenthaler (2011, p. 11), “Open innovation is defined as systematically performing knowledge exploration, retention, and exploitation inside and outside an organization's boundaries throughout the innovation process.”

The main idea behind the concept is that open innovation is the deliberate import and export of knowledge by an organization, to enhance and accelerate its innovation (Xia \& Roper, 2016).

For example, open innovation can be described as a "flow as the attitude of a firm of balancing in flow of knowledge and outflow of knowledge through the prevalence of inbound and outbound practices” (Mazzola, 
Perrone, \& Kamuriwo, 2015 p. 109). There are those who glimpsed in the same words (open innovation) an establishment of ties of innovating firms with other organizations. Copious literature deals with analyzing of what activities must be based on this establishment. Lichtenthaler (2008) refers to firms' dynamic capabilities, internally and externally carrying out the major technology management tasks.

For example, the paper of Parida, Westerberg, and Frishammar (2012) focuses on four distinct inbound open innovation activities, namely: technology scouting, horizontal technology collaboration, vertical technology collaboration, and technology sourcing.

Technology scouting represents an internal search or scanning function related to systematically assessing and observing technology trends in order to detect opportunities and encounter threats in a timely manner (Bianchi, Campodall'Orto, Frattini, \& Vercesi, 2010; Katila, 2002; Laursen \& Salter, 2006; Lichtenthaler, 2007).

The purpose of technology scouting is not to gather large sets of detailed information, but rather to create insights or awareness regarding significant patterns of change in external environment.

Vertical technology collaboration captures collaborative relationships with customers (i.e., vertical downstream collaboration) or supplier (i.e., vertical upstream collaboration) (Baum, Calabrese, \& Silverman, 2000). Vertical technology collaboration could represent a more active involvement of customers and users, as they become key stakeholders in the development process (Chesbrough, 2003a; 2003b; Enkel, Kausch, \& Gassmann, 2005).

Horizontal technology collaboration refers to collaborating with partners that are not part of the value chain of a particular SME. These linkages could include partners from similar or other industries, such as competitors or non-competitors. Technology sourcing represents an open innovation activity for buying or using external technology through IP agreements.

Beyond this classification, it is concord that open innovation may be pursued in many different ways, in terms of: (i) organizational form of acquisition or exploitation and consequent time horizon; (ii) number of partners, from dyadic partnerships to networks, and typologies of partners, from traditional supply chain relationships to collaboration with universities, technical service companies, competitors, firms operating in different industries (Lazzarotti \& Manzini, 2009).

OI helps drive employee productivity, customer loyalty, and better innovation. Hence, open innovation is mostly a strategic choice (Giannopoulou, Yström, \& Ollila, 2011).

Companies can no longer afford to rely entirely on their own knowledge to advance their business, nor can they restrict their innovations to a single path to market (Van De Vrande, Vanhaverbeke, \& Gassman, 2010).

More recently, OI has been not seen as a binary concept—open versus closed-but rather as distinct mixture of external interactions (Brunswicker \& Vanhaverbeke, 2015).

Specifically, open innovation is a four-dimensional phenomenon, where the innovation processes can have an outbound versus an inbound nature (Michelino, Lamberti, Cammarano, \& Caputo, 2015). Still others compare OI to crowdsourcing or co-creation, a way for companies to utilize the ideas and strength of the people outside their organization to make improvements in the internal processes or products. Crowdsourcing can be seen as a part of Chesbrough's Open Innovation Paradigm (Schemmann, Herrmann, Chappin, \& Heimeriks, 2016).

Crowd-sourcing initiatives in drug discovery are still in their infancy (Dorsch, Jurock, Schoepe, Lessl, \& Asadullah, 2015), while it has successfully been used in other sectors for decades (Guittard, Schenk, \& 
Burger-Helmchen, 2015; Bonabeau, 2009; Haller, Bullinger, \& Möslein, 2011).

\section{Open Innovation and Grand Challenge}

Grand challenges are defined as "a family of initiatives fostering innovation to solve key global health and development problems" (Grandchallenges.org). Initially, it was a program launched in the early 1980s by US governor and it is bundle of complex technological goals in different fields, such as computing and communication researches; human genome; nuclear fusion and energy recovery; pharmaceutical drugs; astronomy; turbulence; and many others. Mostly, it has a social value, carried from science to society, firstly, to help solve developmental problems for those most in needs; as the recent case of Ebola pandemia. In general, it refers to value creation for the wellness of society, setting long-run goals, which can be attained through complex technological innovations. In grand challenge, cooperation is essential: it is a multilevel, cross-countries, and cross-organizations form of cooperation for the co-creation of innovation. Goals are extremely costly, complex, and characterized by high uncertainty, ambiguity, and risk. Knowledge is disseminated across a multitude of different actors; it’s specialized, opaque, hard to access. In sum, it refers to main global challenges.

In light of this premise, grand challenge appears as a special kind of open innovation, or, the most emblematic and complex one. Although there's a growing global concern for grand challenges, especially in recent years, literature on open innovation showed such a myopia in framing this family of initiatives in terms of the new innovation paradigm. Examining previous contributions, the first result is that studies on this topic mostly appear in outlet such as Nature (Collins, Patel, Joestl, March, Insel, Daar, \& Glass, 2011), or similar; while journals in managerial fields are almost silent.

Curley (2015) goes beyond coining a new term: Open innovation 2.0 (OI2). Open Innovation 2.0 is a new paradigm based on principles of integrated multidisciplinary collaboration, co-created shared value, cultivated innovation ecosystems, unleashed exponential technologies, and focus on innovation adoption

A core pattern of the OI2 paradigm is the use of the quadruple helix model where government, industry, academia, and civil participants work together to co-create the future and drive structural changes far beyond the scope of what any one organization or person could do alone. In this sense, the concept of open innovation can be understood as a tool capable of solving grand challenge. From this point of view, the literature is relatively poor. Villarreal and Calvo (2015) enlighten the importance of international cooperation in speeding up the process of transferring scientific and technological knowledge from universities to industry.

Based on the evidence found in case study, they propose an extension to the Triple Helix model, incorporating the legislative institution and including the role of international cooperation, as an accelerator of the process of scientific and technological knowledge transfer from the bodies that generate it to industry. This will make it possible to relate the Triple Helix to Open Innovation model from a global perspective.

\section{A Reclassification of Open Innovation According to Two Dimensions: Technological Convergence and Ontology of Openness}

Using as dimensions of analysing the degree of technological convergence among actors and the ontology of openness, it is possible to identify three main types of open innovation: at user's level; within-industry; cross-organizational. The first is a light open innovation type; while the last one is the heaviest of the three forms, and it is characterized by an intense technological effort. Technological convergence refers to the degree of technological homogeneity/heterogeneity between the firm and its partners in open innovation strategy. Differently, openness is defined using the ontological orientation, or the direction of the relationship. Both 
variables are defined by structural characteristics and by the organizational orientation.

The lightest open innovation type is one named collaborative open innovation, where the final user of the innovation is involved in the process. In such case, the required degree of technological convergence is minimum, compared to other types of open innovation. Mostly, it refers to innovation design, as instance as for certain product's attributes. When a firm is open toward other firms operating in the same industry or cluster and there's a similarities in knowledge; standardization of technologies; and a tendency for isomorphism; then, the open innovation type is within-industry focused. In this case, cooperation is more intense than in the previous form. Often an incumbent drives the open innovation process, while other partners mostly follow bandwagon logic. In case of complex technological innovation; the cooperation spans at a cross-organizational level. Innovators operate in different fields or industries, such as universities, research centres, non-competing business sectors; etc. The cross-organizational open innovation is characterized by an extreme degree of openness and of permeability of firm's borders. In this case, the need for technological convergence among partners is massive, in terms of technological isomorphism. Technological convergence allows inbound and outbound knowledge flows, facilitating the knowledge diffusion.

Such categories of open innovation emerge from the recognition of previous works. In particular, cross-organizational open innovation form was frequently and implicitly encompassed in several studies.

Chesbrough and Crowther (2006) argue that universities and other similar entities may absolve a knowledge donor function. In a different work, Chesbrough and Aplleyard (2007) indicate that the value of openness is enhanced with every user, and they embrace business ecosystem logic of open innovation, where the business ecosystem is given by the interplay among different industries. Perkman and Walsh (2007) investigate inter-organizational networks relationship between industries and universities. Such relationship is the collaborative type. Within sector open innovation is common also in SME's networks: "as technology becomes so complex that it cannot be handled by one firm alone, and relevant knowledge is evermore scattered across various firms, collaboration between firms is increasingly regarded as an important factor for success.” (Lee, G. Park, Yoon, \& J. Park, 2010, p. 291). More precisely, information sources in SME's open innovation may be grouped as: within firm; from other firms and market; from universities and research centres; from public information (Lee et al., 2010). This last study identifies two main patterns of open innovation in SMEs: collaboration with other firms and market—-firms in its group; competitors in the industry; non-competitors in industry; customer and user firms; business service providers; suppliers; and collaboration with universities and research centre. While the latter category shows an internal homogeneity; instead, the first one is formed by extremely heterogeneous alliances' patterns. Lichtenthaler (2011) argues that open innovation often happens as a cross-industries commercialization of firm's technological knowledge.

\section{Open Innovation Adoption}

The decision to adopt an open innovation strategy can be based on several motivations. We group factors into two main categories: cost-benefits evaluation based on objective factors; cost-benefits evaluation based on social value and other similar subjective factors. The first category refers to intrinsic value motivations; while, in the second category, we include those factors determining a bandwagon effect. In addition, we further specify each category. As a matter of fact, the adoption can be traced back to structural characteristics, to organizational characteristics, to decision maker characteristics. 


\section{Structural Implications of Open Innovation}

Firm's structure may affect its innovation strategy in different ways. In an empirical investigation, Chesbrough and Crowther (2006) find that open innovation adoption is still in its early-stage in non-high-tech industries. Similarly, other scholars investigate firm size (Van de Vrande, De Jong, Vanhaverbeke, \& De Rochemont, 2009; Lee et al., 2010); pinpointing the existence of a structural and an institutional perspectives of open innovation (Gassmann, Enkel, \& Chesbrough, 2010).

Measures for explotation (venturing; licensing; employee involvement) and exploration (customer involvement; external networking; external participation; oursourcing R\&D; inward licensing) are often used as proxy for OI. Business and technological interdependencies increase with open innovation (Dogson, Gann, \& Salter, 2006), determining a structural complexity.

An important stream of studies investigates structural implication of open innovation in light of absorptive capacity (U. Lichtenthaler \& E. Lichtenthaler, 2009; Robertson, Casali, \& Jacobson, 2012). Firm's structural characteristics determine its openness (Henkel, 2006): organization type and sector of activity; size; age at start; experience gained in R\&D. Structural factors and intrinsic value motivations affect firm's capacities and the decision at a project level, such in the following decision cases: make or buy; integrate or relate; keep or sell (Lichtenthaler, 2011). Openness is the results of those structural characteristics determining the breadth and depth of innovation search (Laursen \& Salter, 2006).

\section{The Adoption of an Open Innovation Logic at the Organizational Level}

Most studies are focused on open innovation adoption at the organizational level. Motivations of adoption are mostly based on intrinsic value factors. Chesbrough and Crowther (2006) argue that adoption can be driven by the need of creating growth options and of exploiting extant knowledge; and by the need for open invention and open coordination in business ecosystems (Chesbrough \& Appleyard, 2007). For SMEs, adoption is mostly linked to market related motives and to dealing with organizational cultural issues. However, SMEs' adoption can be led by network effect (Lee et al., 2010), as well. In particular, authors address open innovation in SME in terms of value constellation: exploration of market opportunities and commercialization are the main reasons at the ground of open innovation alliances.

In collaborative research, open innovation is mostly driven by both knowledge based and financial based factors (Perkman \& Walsh, 2007): bench-level co-operations and co-funding by participating firms and government are the main motivations, especially in the medical field. Their empirical findings show a large diffusion of such relationships. A nourished community of scholars considers knowledge based motivations as driver for open innovation (Dogson, Gann, \& Salter, 2006; Perkman \& Walsh, 2007; Chesbrough \& Crowther, 2006; Cooke, 2005; Almirall \& Casadesus-Masanell, 2010). Innovation technologies affect the way innovation is conceived, shared, and used; creating "new environments for people to think about new options, to engage other parties, such as users, in design, to play or experiment with different futures and to ensure that other technologies are used to maximum effect in the delivery of product, process, and service innovation” (Dogson et al., 2006, p. 335). For Henkel (2006), different firms have heterogeneous rationales for openness decision. However, they mostly show a selective revealing behavior: they adopt open innovation in function of a right balance between openness and intellectual property. In other words, the main driver is the profitability of the initiative, weighed for the possibility of building defensible knowledge barriers. 
At an organizational level, drivers of adoption are firm capabilities (Lichtenthaler, 2011): inventive capacity; absorptive capacity; transformative capacity; connective capacity; innovative capacity, and desorptive capacity. The last one is related to the outward technology transfer. Other authors link open innovation adoption to network effect, and, namely, to bandwagon behaviors (Dittrich \& Duysters, 2007).

On the converse, hindering factors can be the cost of open innovation, due to uncertainty of managing dispersed networks of knowledge; high level of interdependencies; the ambiguity of proprietary rights for intellectual property (Dogson et al., 2006). Hindering factors of adoption can be grouped in intrinsic value factors-funding difficulties; risk; market structure-and bandwagon motivations-fear of imitation; uncertainty; lack of information; needless of additional innovation (Lee et al., 2010). Last, among other intrinsic based motivations there are high transaction costs (Christensen, Olesen, \& Kjær, 2005).

\section{The Adoption of an Open Innovation Logic at an Individual Level}

Studies on open innovation adoption at the individual level are more scant than the former analyzed category. Usually, individual adoptions are driven by perceptions; belief; social contagion; and network externalities.

In a cross-industries survey, Chesbrough and Crowther (2006) interview top managers of various firms. Among other findings, they argue that open innovation adoption is not primarily employed for intrinsic value motivations. Consistently, the network effect and the momentum behind a novelty can lead to adoptions (Chesbrough \& Appleyard, 2007). Similarly, individual decision to adopt may be linked to network effect: participating in an open innovation network can offer more knowledge solutions, merely than relying on closed innovation (Terwiesch \& Xu, 2008).

Typically, at an individual level, judgments on open innovation adoptions are biased by extreme uncertainty. Uncertainty often is of the technical and market types (Chesbrough, 2004): hence, open innovation decision may appear as a pure bet, as the poker game. As a consequence, traditional metrics lead to false negative and false positive results. At an individual level, there is a latent value in managing false negative and false positive results. Lichtenthaler (2011) suggests that open innovation adoption is determined by different drivers at a multiple level: as instance, attitudes of individual may contrast positive management mechanism. Among other examples of attitudes, there are: the not-invented and not-sold-here syndromes; the positive buy-in attitude toward externally exploring knowledge; knowledge retention and not-connected-here syndrome; the positive relate-out and sell-out attitudes (Lichtenthaler, 2011). Human and social capital is also seen as drivers of adoption; since individuals act as knowledge brokers and boundaries spanners (Fleming \& Waguespack, 2007).

\section{Concluding Remarks, Research Limitations, and Suggestions for Future Studies}

As antecedent scholars suggest, it is of importance to create a conceptual framework which allows understanding how open innovation can add value in knowledge intensive processes (Enkel et al., 2009). In business ecosystems, the technological convergence among actors can help balance the value creation with value capturing (Chesbrough, 2007). Since judgments on the value of open innovation adoption can be biased by false negative results (Chesbrough, 2004), new metrics for the correct evaluation of open innovation initiatives may help firms salvage value. This situation occurs when the innovation path in unknowable and the decision is harnessed by uncertainty. 
However, the value capture also depends on the risk of the initiative: sustainability of risk can determine the decision to innovate and may drive the choice between closed and open innovation.

Current systematic literature review and conceptual model tackle many goals. The wealth of interest on open innovation led to a very fragmented panorama, and, so, there's such a confusion on what is open innovation. First, we make an attempt of mapping main definitions and taxonomies of open innovation, basing on a multi-level analysis of previous contributions. Second, we map main extant literature gaps: ontology of openness in relationship to technological convergence; grand challenges and open innovation.

The increasing technological convergence can foster open innovation. Both open innovation and technological convergence are ideally the best way to solve societal grand challenges. Future research should investigate how open innovation can be used for grand challenges and how technological convergence can be increased to promote innovation.

Our study is affected by some limitations. First, it lacks of content and bibliometric analyses, both useful to depict a more precise framework of the status-of-the-art and of research streams.

Finally, the relevance of grand challenges claims for more systematic and focused managerial studies, in particular in light of open innovation model.

\section{References}

Almirall, E., \& Casadesus-Masanell, R. (2010). Open versus closed innovation: A model of discovery and divergence. Academy of Management Review, 35(1), 27-47.

Baum, J. A., Calabrese, T., \& Silverman, B. S. (2000). Don’t go it alone: Alliance network composition and startups' performance in Canadian biotechnology. Strategic Management Journal, 267-294.

Bianchi, M., Campodall'Orto, S., Frattini, F., \& Vercesi, P. (2010). Enabling open innovation in small- and medium-sized enterprises: How to find alternative applications for your technologies. R\&D Management, 40(4), 414-431.

Bianchi, M., Cavaliere, A., Chiaroni, D., Frattini, F., \& Chiesa, V. (2011). Organizational modes for open innovation in the bio-pharmaceutical industry: An exploratory analysis. Technovation, 31(1), 22-33.

Bogers, M. (2011). The open innovation paradox: knowledge sharing and protection in R\&D collaborations. European Journal of Innovation Management, 14(1), 93-117.

Bonabeau, E. (2009). Decisions 2.0: The power of collective intelligence. MIT Sloan Management Review, 50 (2), 45.

Brunswicker, S., \& Vanhaverbeke, W. (2015). Open innovation in small and medium-sized enterprises (SMEs): External knowledge sourcing strategies and internal organizational facilitators. Journal of Small Business Management, 53(4), 1241-1263.

Chesbrough, H. (2003a). The logic of open innovation: Managing intellectual property. California Management Review, $45(3), 33$.

Chesbrough, H. (2003b). Open innovation: The new imperative for creating and profiting from technology. Boston (MA): Harvard Business School Press.

Chesbrough, H. (2004). Managing open innovation. Research Technology Management, 47(1), 23.

Chesbrough, H. (2012). Open innovation: Where we've been and where we're going. Research-Technology Management, 55(4), 20-27.

Chesbrough, H. W. (2007). Why companies should have open business models. MIT Sloan Management Review, $48(2), 22$.

Chesbrough, H. W., \& Appleyard, M. M. (2007). Open innovation and strategy. California Management Review, 50(1), 57-76.

Chesbrough, H., \& Crowther, A. K. (2006). Beyond high tech: Early adopters of open innovation in other industries. R\&D Management, 36(3), 229-236.

Christensen, J. F., Olesen, M. H., \& Kjær, J. S. (2005). The industrial dynamics of open innovation. Evidence from the transformation of consumer electronics. Research Policy, 34(10), 1533-1549.

Collins, P. Y., Patel, V., Joestl, S. S., March, D., Insel, T. R., Daar, A. S., \& Glass, R. I. (2011). Grand challenges in global mental health. Nature, 475(7354), 27-30.

Cooke, P. (2005). Regionally asymmetric knowledge capabilities and open innovation: Exploring “Globalisation 2"-A new model of industry organisation. Research Policy, 34(8), 1128-1149. 
Curley, M. (2015). The evolution of open innovation. Journal of Innovation Management, 3(2), 9-16.

Dahlander, L., \& Gann, D. M. (2010). How open is innovation? Research Policy, 39(6), 699-709.

Dahlander, L., Frederiksen, L., \& Rullani, F. (2008). Online communities and open innovation. Industry and Innovation, 15(2), 115-123.

Dittrich, K., \& Duysters, G. (2007). Networking as a means to strategy change: the case of open innovation in mobile telephony. Journal of Product Innovation Management, 24(6), 510-521.

Dodgson, M., Gann, D., \& Salter, A. (2006). The role of technology in the shift towards open innovation: The case of Procter \& Gamble. R\&D Management, 36(3), 333-346.

Dorsch, H., Jurock, A. E., Schoepe, S., Lessl, M., \& Asadullah, K. (2015). Grants4Targets: An open innovation initiative to foster drug discovery collaborations. Nature Reviews Drug Discovery, 14(1), 74-76.

Elmquist, M., Fredberg, T., \& Ollila, S. (2009). Exploring the field of open innovation. European Journal of Innovation Management, 12(3), 326-345.

Enkel, E., Gassmann, O., \& Chesbrough, H. (2009). Open R\&D and open innovation: Exploring the phenomenon. $R \& D$ Management, 39(4), 311-316.

Enkel, E., Kausch, C., \& Gassmann, O. (2005). Managing the risk of customer integration. European Management Journal, 23(2), 203-213.

Fleming, L., \& Waguespack, D. M. (2007). Brokerage, boundary spanning, and leadership in open innovation communities. Organization Science, 18(2), 165-180.

Gassmann, O., \& Enkel, E. (2004). Towards a theory of open innovation: Three core process archetypes. R\&D Management Conference, 6, 1-18.

Gassmann, O., Enkel, E., \& Chesbrough, H. (2010). The future of open innovation. R\&D Management, 40(3), $213-221$.

Giannopoulou, E., Yström, A., \& Ollila, S. (2011). Turning open innovation into practice: Open innovation research through the lens of managers. International Journal of Innovation Management, 15(03), 505-524

Giannopoulou, E., Yström, A., Ollila, S., Fredberg, T., \& Elmquist, M. (2010). Implications of openness: A study into (all) the growing literature on open innovation. Journal of Technology Management \& Innovation, 5(3), 162-180.

Greco, M., Grimaldi, M., \& Cricelli, L. (2015). Open innovation actions and innovation performance: A literature review of European empirical evidence. European Journal of Innovation Management, 18(2), 150-171.

Guittard, C., Schenk, E., \& Burger-Helmchen, T. (2015). Crowdsourcing and the evolution of a business ecosystem. In Advances in crowdsourcing (pp. 49-62). Springer International Publishing.

Haller, J. B., Bullinger, A. C., \& Möslein, K. M. (2011). Innovation contests. Business \& Information Systems Engineering, 3(2), 103-106.

Henkel, J. (2006). Selective revealing in open innovation processes: The case of embedded Linux. Research Policy, 35(7), 953-969.

Huizingh, E. K. (2011). Open innovation: State of the art and future perspectives. Technovation, 31(1), 2-9.

Katila, R. (2002). New product search over time: past ideas in their prime? Academy of Management Journal, 45(5), 995-1010.

Laursen, K., \& Salter, A. (2006). Open for innovation: the role of openness in explaining innovation performance among UK manufacturing firms. Strategic Management Journal, 27(2), 131-150.

Lazzarotti, V., \& Manzini, R. (2009). Different modes of open innovation: A theoretical framework and an empirical study. International Journal of Innovation Management, 13(04), 615-636.

Lee, S., Park, G., Yoon, B., \& Park, J. (2010). Open innovation in SMEs-An intermediated network model. Research Policy, 39(2), 290-300.

Lichtenthaler, U. (2007). The drivers of technology licensing: An industry comparison. California Management Review, 49(4), 67-89.

Lichtenthaler, U. (2008). Open innovation in practice: An analysis of strategic approaches to technology transactions. Engineering Management, IEEE Transactions on Engineering Management, 55(1), 148-157.

Lichtenthaler, U. (2011). Open innovation: Past research, current debates, and future directions. The Academy of Management Perspectives, 25(1), 75-93.

Lichtenthaler, U., \& Lichtenthaler, E. (2009). A capability-based framework for open innovation: Complementing absorptive capacity. Journal of Management Studies, 46(8), 1315-1338.

Mazzola, E., Perrone, G., \& Kamuriwo, D. S. (2015). Network embeddedness and new product development in the biopharmaceutical industry: The moderating role of open innovation flow. International Journal of Production Economics, 160, 106-119. 
Michelino, F., Lamberti, E., Cammarano, A., \& Caputo, M. (2015). Measuring open innovation in the bio-pharmaceutical industry. Creativity and Innovation Management, 24(1), 4-28.

Ozkan, N. N. (2015). An example of open innovation: P\&G. Procedia-Social and Behavioral Sciences, 195, 1496-1502.

Parida, V., Westerberg, M., \& Frishammar, J. (2012). Inbound open innovation activities in high-tech SMEs: The impact on innovation performance. Journal of Small Business Management, 50(2), 283-309.

Perkmann, M., \& Walsh, K. (2007). University-industry relationships and open innovation: Towards a research agenda. International Journal of Management Reviews, 9(4), 259-280.

Robertson, P. L., Casali, G. L., \& Jacobson, D. (2012). Managing open incremental process innovation: Absorptive capacity and distributed learning. Research Policy, 41(5), 822-832.

Schemmann, B., Herrmann, A. M., Chappin, M. M., \& Heimeriks, G. J. (2016). Crowdsourcing ideas: Involving ordinary users in the ideation phase of new product development. Research Policy, 45(6), 1145-1154

Schroll, A., \& Mild, A. (2012). A critical review of empirical research on open innovation adoption. Journal für Betriebswirtschaft, 62(2), 85-118.

Schueffel, P. E., \& Vadana, I. I. (2015). Open Innovation in the financial services sector-A global literature review. Journal of Innovation Management, 3(1), 25-48.

Sieg, J. H., Wallin, M. W., \& Von Krogh, G. (2010). Managerial challenges in open innovation: A study of innovation intermediation in the chemical industry. R\&D Management, 40(3), 281-291.

Spithoven, A., Clarysse, B., \& Knockaert, M. (2011). Building absorptive capacity to organise inbound open innovation in traditional industries. Technovation, 31(1), 10-21.

Terwiesch, C., \& Xu, Y. 2008. Innovation contests, open innovation, and multiagent problem solving. Management Science, 54(9), $1529-1543$.

Trott, P., \& Hartmann, D. A. P. (2009). Why open innovation is old wine in new bottles. International Journal of Innovation Management, 13(04), 715-736.

Valera, L. L. C. (1997). Open innovation challenges. Nature Biotechnology, 15, 239-243.

Van de Vrande, V., De Jong, J. P., Vanhaverbeke, W., \& De Rochemont, M. (2009). Open innovation in SMEs: Trends, motives and management challenges. Technovation, 29(6), 423-437.

Villarreal, O., \& Calvo, N. (2015). From the Triple Helix model to the Global Open Innovation model: A case study based on international cooperation for innovation in Dominican Republic. Journal of Engineering and Technology Management, 35, 71-92.

West, J., \& Bogers, M. (2014). Leveraging external sources of innovation: A review of research on open innovation. Journal of Product Innovation Management, 31(4), 814-831.

West, J., \& Gallagher, S. (2006). Challenges of open innovation: The paradox of firm investment in open-source software. $R \& D$ Management, 36(3), 319-331.

West, J., Salter, A., Vanhaverbeke, W., \& Chesbrough, H. (2014). Open innovation: The next decade. Research Policy, 43(5), 805-811.

Wikhamn, B. R., \& Wikhamn, W. (2013). Structuring of the open innovation field. Journal of Technology Management \& Innovation, 8(3), 173-185.

Wikhamn, B. R. (2013). Two different perspectives on open innovation-Libre versus control. Creativity and Innovation Management, 22(4), 375-389.

Xia, T., \& Roper, S. (2016). Unpacking open innovation: Absorptive capacity, exploratory and exploitative openness, and the growth of entrepreneurial biopharmaceutical firms. Journal of Small Business Management, 54(3), 931-952 


\section{Appendix}

Table 1

List of Main Selected Contribution Basing on Citation Numbers

\begin{tabular}{|c|c|c|}
\hline Title & Authors & Year \\
\hline Open innovation: The new imperative for creating and profiting from technology & H. W. Chesbrough & 2006 \\
\hline $\begin{array}{l}\text { Open for innovation: The role of openness in explaining innovation performance among UK } \\
\text { manufacturing firms }\end{array}$ & K. Laursen, A. Salter & 2006 \\
\hline The era of open innovation & H. W. Chesbrough & 2006 \\
\hline Open innovation: Researching a new paradigm & H. Chesbrough, W. Vanhaverbeke, J. West & 2006 \\
\hline How to improve R\&D productivity: The pharmaceutical industry’s grand challenge & S. M. Paul, D. S. Mytelka, C. T. Dunwiddie & 2010 \\
\hline How open is innovation? & L. Dahlander, D. M. Gann & 2010 \\
\hline Beyond high tech: Early adopters of open innovation in other industries & H. Chesbrough, A. K. Crowther & 2006 \\
\hline Open innovation: A new paradigm for understanding industrial innovation & H. Chesbrough & 2006 \\
\hline Open innovation in SMEs: Trends, motives and management challenges & V. Van de Vrande, J. P. J. De Jong, W. Vanhaverbeke & 2009 \\
\hline Open R\&D and open innovation: Exploring the phenomenon & E. Enkel, O. Gassmann, H. Chesbrough & 2009 \\
\hline Opening up the innovation process: Towards an agenda & O. Gassmann & 2006 \\
\hline Open innovation: State of the art and future perspectives & E. K. R. E. Huizingh & 2011 \\
\hline Challenges of open innovation: The paradox of firm investment in open-source software & J. West, S. Gallagher & 2006 \\
\hline Grand challenges in global mental health & $\begin{array}{l}\text { P. Y. Collins, V. Patel, S. S. Joestl, D. March, T. R. } \\
\text { Insel }\end{array}$ & 2011 \\
\hline Open innovation and strategy & H. W. Chesbrough, M. M. Appleyard & 2007 \\
\hline The future of open innovation & O. Gassmann, E. Enkel, H. Chesbrough & 2010 \\
\hline Towards a theory of open innovation: Three core process archetypes & O. Gassmann, E. Enkel & 2004 \\
\hline Why companies should have open business models & H. W. Chesbrough & 2007 \\
\hline University-industry relationships and open innovation: Towards a research agenda & M. Perkmann, K. Walsh & 2007 \\
\hline Open innovation challenges & L. L. C. Valera & 1997 \\
\hline Managing open innovation & H. Chesbrough & 2004 \\
\hline The role of technology in the shift towards open innovation: the case of Procter \& Gamble & M. Dodgson, D. Gann, A. Salter & 2006 \\
\hline Selective revealing in open innovation processes: The case of embedded Linux & J. Henkel & 2006 \\
\hline Open innovation in SMEs: An intermediated network model & S. Lee, G. Park, B. Yoon, J. Park & 2010 \\
\hline The industrial dynamics of open innovational: Evidence from the transformation of consumer electronics & J. F. Christensen, M. H. Olesen, J. S. Kjær & 2005 \\
\hline A capability based framework for open innovation: Complementing absorptive capacity & U. Lichtenthaler, E. Lichtenthaler & 2009 \\
\hline $\begin{array}{l}\text { Regionally asymmetric knowledge capabilities and open innovation: Exploring globalisation: A new } \\
\text { model of industry organisation }\end{array}$ & P. Cooke & 2005 \\
\hline
\end{tabular}


(Table 1 continued)

Open innovation: Past research, current debates, and future directions

U. Lichtenthaler

2011

Networking as a means to strategy change: The case of open innovation in mobile telephony

K. Dittrich, G. Duysters

2007

Building absorptive capacity to organise inbound open innovation in traditional industries

A. Spithoven, B. Clarysse, M. Knockaert 2011

Innovation contests, open innovation, and multiagent problem solving

C. Terwiesch, Y. Xu

Open innovation in practice: An analysis of strategic approaches to technology transaction

U. Lichtenthaler 2008

The logic of open innovation: Managing intellectual property

Brokerage, boundary spanning, and leadership in open innovation communities

Open versus closed innovation: A model of discovery and divergence

H. Chesbrough

L. Fleming, D. M. Waguespack

Why open innovation is old wine in new bottles

Getting clear about communities in open innovation

E. Almirall, R. Casadesus 2010

P. Trott, D. A. P. Hartmann 2009

Open and closed innovation: different innovation cultures for different strategies

J. West, K. R. Lakhani 2008

Open innovation: a research agenda

P. Herzog, J. Leker

J. West, W. Vanhaverbeke, H. Chesbrough 2008

The open innovation journey: How firms dynamically implement the emerging innovation management paradigm

The interorganizational context of open innovation

D. Chiaroni, V. Chiesa, F. Frattini

W. Vanhaverbeke

2011

Organisational modes for open innovation in the bio-pharmaceutical industry: An exploratory analysis

Outbound open innovation and its effect on firm performance: examining environmental influences

Open innovation in value networks

Open innovation in practice

Determinants and archetype users of open innovation

Patterns of open innovation in open source software

Open innovation: The Dutch treat: Challenges in thinking in business models

M. Bianchi, A. Cavaliere, D. Chiaroni, F. Frattini, V.

Chiesa

U. Lichtenthaler

W. Vanhaverbeke, M. Cloodt

R. Kirschbaum

M. M. Keupp, O. Gassmann

J. West, S. Gallagher

Unravelling the process from closed to open innovation: Evidence from mature, asset intensive industries D. Chiaroni, V. Chiesa, F. Frattini

Leveraging external sources of innovation: A review of research on open innovation

J. West, M. Bogers

M. Elmquist, T. Fredberg, S. Ollila

Exploring the field of open innovation

R. Rohrbeck, K. Hölzle, H. G. Gemünden

Opening up for competitive advantage: How Deutsche Telekom creates an open innovation ecosystem

Living labs and open innovation: Roles and applicability

E. Almirall, J. Wareham

M. Antikainen, M. Mäkipää, M. Ahonen

Motivating and supporting collaboration in open innovation

Responsible research and innovation: From science in society to science for society, with society

wen, P. Macnaghten

H. W. Chesbrough, A. R. Garman

The next step in open innovation

J. Bughin, M. Chui, B. Johnson

Co-operation and co-opetition as open innovation practices in the service sector: Which influence on

innovation novelty?

A. L. Mention 
(Table 1 continued)

Inbound open innovation activities in high-tech SMEs: The impact on innovation performance

V. Parida, M. Westerberg

2012

Bringing open innovation to services

Role models for radical innovations in times of open innovation

H. W. Chesbrough

Different modes of open innovation: A theoretical framework and an empirical study

H. G. Gemünden, S. Salomo

2011

Innovation communities: The role of networks of promotors in Open Innovation

V. Lazzarotti, R. Manzin

New ventures based on open innovation: An empirical analysis of start-up firms in embedded Linux

Does appropriability enable or retard open innovation

M. Gruber, J. Henkel

J. West

Managerial challenges in open innovation: A study of innovation intermediation in the chemical industry J. H. Sieg, M. W. Wallin, G. Von Krogh

Open innovation: Where we've been and where we're going

H. Chesbrough

Open innovation and the stage-gate process: A revised model for new product development

J. Gronlund, D. R. Sjodin, J. Frishammar

J. F. Christensen

Wither core competency for the large corporation in an open innovation world

W. Vanhaverbeke, V. Van de Vrande

Understanding the advantages of open innovation practices in corporate venturing in terms of real

D. Faems, M. De Visser, P. Andries 2010

Technology Alliance Portfolios and Financial Performance: Value enhancing and cost increasing effects

of open innovation

Policies for open innovation: Theory, framework and cases

Dynamics of open innovation in the food industry

Managing open innovation in biotechnology

Online communities and open innovation

J. P. J. De Jong, W. Vanhaverbeke, T. Kalvet

S. Sarkar, A. I. A. Costa

T. J. Fetterhoff, D. Voelkel

L. Dahlander, L. Frederiksen, F. Rullan

H. Chesbrough, W. Vanhaverbeke, J. West

L. Mortara, T. Minshall

How do large multinational companies implement open innovation?

The open innovation paradox: Knowledge sharing and protection in R\&D collaborations

M. Bogers

Is open innovation a field of study or a communication barrier to theory development?

A. J. Groen, J. D. Linton

Broadening the scope of open innovation: Past research, current state and future directions

V. Van De Vrande, W. Vanhaverbeke

J. West, A Salter, W. Vanhaverbeke, H. Chesbroug

How constraints and knowledge impact open innovation

H. Garriga, G. von Krogh

Turning open innovation into practice: Open innovation research through the lens of managers

E. Giannopoulou, A. Yström, S. Ollila

E. Giannopoulou, A. Yström, S. Ollila

A. Schroll, A. Mild

2006

2006

Implications of openness: A study into (all) the growing literature on open innovation

2010

2012

2010 2006

A critical review of empirical research on open innovation adoption 
Table 2

Extract of Systematic Literature Mapping

\begin{tabular}{|c|c|c|c|c|c|c|c|}
\hline Title & Authors & Journal & Year & $\begin{array}{l}\text { Theory/Topic (es. } \\
\text { Organizational theory; } \\
\text { absorptive capacity) }\end{array}$ & $\begin{array}{l}\text { Level of OI } \\
\text { (user/within } \\
\text { industry/across } \\
\text { industries): } \\
\text { ontology of } \\
\text { openness } \\
\end{array}$ & $\begin{array}{l}\text { Level of analysis } \\
\text { (individual/organiz } \\
\text { ational/structural) }\end{array}$ & $\begin{array}{l}\text { Function of OI } \\
\text { adoption (based on } \\
\text { intrinsic value } \\
\text { characteristics/based } \\
\text { on bandwagon } \\
\text { factors) }\end{array}$ \\
\hline $\begin{array}{l}\text { Outbound open innovation } \\
\text { and its effect on firm } \\
\text { performance: Examining } \\
\text { environmental influences }\end{array}$ & U. Lichtenthaler & R\&D Management & 2009 & $\begin{array}{l}\text { Outbound open innovation } \\
\text { strategies/transaction cost } \\
\text { theory }\end{array}$ & Across industries & Organizational & Instrinsic \\
\hline $\begin{array}{l}\text { Determinants and archetype } \\
\text { users of open innovation }\end{array}$ & $\begin{array}{l}\text { M. M. Keupp, O. } \\
\text { Gassmann }\end{array}$ & R\&D Management & 2009 & $\begin{array}{l}\text { The association between } \\
\text { impediments to innovation } \\
\text { and OI }\end{array}$ & Within industry & Organizational & \\
\hline $\begin{array}{l}\text { Inbound open innovation } \\
\text { activities in high-tech } \\
\text { SMEs: The impact on } \\
\text { innovation performance }\end{array}$ & $\begin{array}{l}\text { V. Parida, M. } \\
\text { Westerberg }\end{array}$ & $\begin{array}{l}\text { Journal of Small } \\
\text { Business } \\
\text { Management }\end{array}$ & 2012 & $\begin{array}{l}\text { The effects of four inbound } \\
\text { open innovation activities on } \\
\text { innovation performance of } \\
\text { SMEs. }\end{array}$ & Across industries & Organizational & Intrinsic value \\
\hline $\begin{array}{l}\text { Different modes of open } \\
\text { innovation: A theoretical } \\
\text { framework and an empirical } \\
\text { study }\end{array}$ & $\begin{array}{l}\text { V. Lazzarotti, R. } \\
\text { Manzini }\end{array}$ & $\begin{array}{l}\text { International } \\
\text { journal of } \\
\text { innovation }\end{array}$ & 2009 & $\begin{array}{l}\mathrm{R} \& \mathrm{D} \text { and organizational } \\
\text { context }\end{array}$ & $\begin{array}{l}\text { Within industry, } \\
\text { cross industry }\end{array}$ & $\begin{array}{l}\text { Individual, } \\
\text { organizational, } \\
\text { structural }\end{array}$ & Intrinsec value \\
\hline $\begin{array}{l}\text { Open innovation and the } \\
\text { stage-gate process: A } \\
\text { revised model for new } \\
\text { product development }\end{array}$ & $\begin{array}{l}\text { J. Gronlund, D. R. } \\
\text { Sjodin, J. } \\
\text { Frishammar }\end{array}$ & $\begin{array}{l}\text { California } \\
\text { Management } \\
\text { Review }\end{array}$ & 2010 & $\mathrm{R} \& \mathrm{D}$ context & $\begin{array}{l}\text { Within industry, } \\
\text { cross industry }\end{array}$ & Individual, & Intrinsec value \\
\hline $\begin{array}{l}\text { Wither core competency for } \\
\text { the large corporation in an } \\
\text { open innovation world }\end{array}$ & J. F. Christensen & $\begin{array}{l}\text { Open innovation: } \\
\text { Researching a new } \\
\text { paradigm }\end{array}$ & 2006 & Corporate strategy & $\begin{array}{l}\text { User, within } \\
\text { industries }\end{array}$ & $\begin{array}{l}\text { Organizational, } \\
\text { structural }\end{array}$ & Intrinsec value \\
\hline $\begin{array}{l}\text { Understanding the } \\
\text { advantages of open } \\
\text { innovation practices in } \\
\text { corporate venturing in terms } \\
\text { of real options }\end{array}$ & $\begin{array}{l}\text { W. Vanhaverbeke, } \\
\text { V. Van de Vrande }\end{array}$ & $\begin{array}{l}\text { Creativity and } \\
\text { Innovation } \\
\text { Management }\end{array}$ & 2008 & Organizational learning & Within industry & $\begin{array}{l}\text { Organizational, } \\
\text { structural }\end{array}$ & Intrinsec value \\
\hline $\begin{array}{l}\text { Managing open innovation } \\
\text { in biotechnology }\end{array}$ & $\begin{array}{l}\text { T. J. Fetterhoff, D. } \\
\text { Voelkel }\end{array}$ & $\begin{array}{l}\text { Research-Technolo } \\
\text { gy Management }\end{array}$ & 2006 & Innovation process & Across industries & Structural & Intrinsec value \\
\hline $\begin{array}{l}\text { Online communities and } \\
\text { open innovation }\end{array}$ & $\begin{array}{l}\text { L. Dahlander, L. } \\
\text { Frederiksen, F. } \\
\text { Rullani }\end{array}$ & $\begin{array}{l}\text { Industry and } \\
\text { innovation }\end{array}$ & 2008 & Organizational theory & User & $\begin{array}{l}\text { Organizational } \\
\text { community }\end{array}$ & Bandwagon \\
\hline
\end{tabular}


(Table 2 continued)

\begin{tabular}{|c|c|c|c|c|c|c|c|}
\hline $\begin{array}{l}\text { The open innovation } \\
\text { paradox: Knowledge } \\
\text { sharing and protection in } \\
\text { R\&D collaborations }\end{array}$ & M. Bogers & $\begin{array}{l}\text { European Journal of } \\
\text { Innovation } \\
\text { Management }\end{array}$ & 2011 & Theory & $\begin{array}{l}\text { Within industry, } \\
\text { cross industry }\end{array}$ & $\begin{array}{l}\text { Structural, } \\
\text { organizational }\end{array}$ & $\begin{array}{l}\text { Intrinsec value } \\
\text { characteristics }\end{array}$ \\
\hline $\begin{array}{l}\text { Broadening the scope of } \\
\text { open innovation: Past } \\
\text { research, current state and } \\
\text { future directions }\end{array}$ & $\begin{array}{l}\text { V. Van De Vrande, } \\
\text { W. Vanhaverbeke }\end{array}$ & $\begin{array}{l}\text { International } \\
\text { Journal }\end{array}$ & 2010 & Organization theory & Within industry & $\begin{array}{l}\text { Individual, } \\
\text { organizational }\end{array}$ & Intrinsec value \\
\hline $\begin{array}{l}\text { How constraints and } \\
\text { knowledge impact open } \\
\text { innovation }\end{array}$ & $\begin{array}{l}\text { H. Garriga, G. von } \\
\text { Krogh }\end{array}$ & $\begin{array}{l}\text { Strategic } \\
\text { Management }\end{array}$ & 2013 & Organizational learning & $\begin{array}{l}\text { Cross } \\
\text { organizations }\end{array}$ & Organizational & Intrinsec value \\
\hline $\begin{array}{l}\text { Open innovation in small } \\
\text { and medium-sized } \\
\text { enterprises (SMEs): } \\
\text { External knowledge } \\
\text { sourcing strategies and } \\
\text { internal organizational } \\
\text { facilitators }\end{array}$ & $\begin{array}{l}\text { S. Brunswicker, } \\
\text { W. Vanhaverbeke }\end{array}$ & $\begin{array}{l}\text { Journal of Small } \\
\text { Business } \\
\text { Management }\end{array}$ & 2015 & $\begin{array}{l}\text { Nature of external knowledge } \\
\text { sourcing and the facilitating } \\
\text { role of internal practices for } \\
\text { managing innovation }\end{array}$ & Across industries & Structural & Intrincs value \\
\hline $\begin{array}{l}\text { Business models for open } \\
\text { innovation: Matching } \\
\text { heterogeneous open } \\
\text { innovation strategies with } \\
\text { business model dimensions }\end{array}$ & T. Saebi, N. J. Foss & $\begin{array}{l}\text { European } \\
\text { Management } \\
\text { Journal }\end{array}$ & 2015 & $\begin{array}{l}\text { Organizational antecedents of } \\
\text { successful open innovation /// } \\
\text { Topic is busuiness models }\end{array}$ & $\begin{array}{l}\text { Depending on } \\
\text { business models } \\
\text { adopted }\end{array}$ & $\begin{array}{l}\text { Structural: } \\
\text { business-unit level }\end{array}$ & Intrinsic value \\
\hline $\begin{array}{l}\text { Match and manage: The use } \\
\text { of knowledge matching and } \\
\text { project management to } \\
\text { integrate knowledge in } \\
\text { collaborative inbound open } \\
\text { innovation }\end{array}$ & $\begin{array}{l}\text { N. Lakemond, L. } \\
\text { Bengtsson, K. } \\
\text { Laursen, F. Tell }\end{array}$ & $\begin{array}{l}\text { Industrial and } \\
\text { Corporate }\end{array}$ & 2016 & $\begin{array}{l}\text { Knowledge integration and } \\
\text { knowledge governance } \\
\text { theories (second step } \\
\text { identified by West and } \\
\text { Bogers: integrating } \\
\text { knowledge) - Topic: two types } \\
\text { knowledge governance } \\
\text { procedures in collaborative } \\
\text { inbound open innovation: } \\
\text { project management and } \\
\text { knowledge matching }\end{array}$ & Within industry & Firm level & Intrinsic value \\
\hline $\begin{array}{l}\text { Unpacking open innovation: } \\
\text { Absorptive capacity, } \\
\text { exploratory and exploitative } \\
\text { openness, and the growth of } \\
\text { entrepreneurial } \\
\text { biopharmaceutical firms }\end{array}$ & T. Xia, S. Roper & $\begin{array}{l}\text { Journal of Small } \\
\text { Business } \\
\text { Management }\end{array}$ & 2016 & $\begin{array}{l}\text { Relationship between } \\
\text { absorptive capacity (ACAP) + } \\
\text { external relationships and } \\
\text { their effects on growth }\end{array}$ & Across industries & & Instrinsic value \\
\hline
\end{tabular}


The main motivations

for the adoption of $\mathrm{OI}$

by SMEs are keeping

up with market

developments,

remaining competitive

The identification and

characterization of open

C. Verbano, M.

innovation profiles in italian Crema, $\mathrm{K}$.

small and medium-sized Venturini enterprises
Journal of Small

Business
Identify and characterize different profiles of $\mathrm{OI}$ in SME
Within industry Organizational

demand, developing

products more quickly

and effectively,

incorporating

technologies and new

knowledge in current

products, and

improving the

innovation process

and the corporate

brand reputation

Measuring open innovation
in the bio-pharmaceutical
industry

Does patenting help or hinder open innovation?

Evidence from new entrants

in the solar industry

Information technology and

open innovation: A strategic

alignment perspective

F. Michelino, E.

Lamberti, A.

Cammarano

Creativity and

Innovation

Management

A. K. Z. Benjamin Industrial and

Balsmeier, $\mathrm{H}$. Corporate Change

Chesbrough

Information \&

$\begin{array}{ll}\text { T. Cui, H. J. Ye, } & \text { Information \& } \\ \text { H. Heo, J. Li } & \text { Management }\end{array}$

2015

2015

Measuring open innovation

Within industry Structural

Association between OI and

IP is of a uniform nature, or

whether it differs across Across industries Organizational/stru Intrinsic value

relationships that vary in

terms of technology intensity

Link between organizational

innovation performance and

the alignment of IT strategy

Instrinsic value

and open innovation strategy

Focus specifically on the

inbound open innovation

element which involves the

acquisition and leveraging of

Inbound open innovation for S. R. Sisodiya, J. Industrial

enhanced performance: $\quad$ L. Johnson, Y. Marketing

Enablers and opportunities Grégoire Management

external inputs for new
product development, that is,

Structual

integrating external inputs

into a firm's extant new

product technologies. 